\title{
Correction to: Urban water and food security in this century and beyond: Resource-smart cities and residents
}

\author{
Jan-Olof Drangert $(D$
}

Published online: 16 January 2021

\section{Correction to: Ambio}

https://doi.org/10.1007/s13280-020-01373-1

In the original publication, Table 1 was processed incorrectly during the typesetting and publication process. The final column of Washing clothes should be "-10" and not " -1 " in Table 1. The correct version of Table 1 is provided in this correction.

The original article has been corrected. 
Table 1 Various measures by urban households in some countries to reduce, reuse and recycle water in litres per person per day and nutrients as percentage of imported mined P. Sources: Gleick (1993), Suzuki et al. (2010), Svenskt Vatten (2017), Drangert et al. (2018)

Measures to save $\mathrm{H}_{2} \mathrm{O}$ in some rich cities/countries

Measures to save $\mathrm{P}$ in EU member states

\begin{tabular}{|c|c|c|c|c|c|c|}
\hline & $\begin{array}{l}\text { USA ca } 1990 \\
\text { Range }\end{array}$ & $\begin{array}{l}\text { USA } \\
\text { Least lpcd }\end{array}$ & $\begin{array}{l}\text { Sweden today } \\
\text { (L) }\end{array}$ & Aim in lpcd (L) & & $\begin{array}{l}\text { EU import } \\
(\%)\end{array}$ \\
\hline \multicolumn{7}{|l|}{ Step 1: reduce } \\
\hline Hygiene eg. shower & 20-30 (L per min) & 100-150 L 5 min/day & 60 & -30 & No $\mathrm{P}$ in detergents & -6 \\
\hline Toilet flush & 10-30 (L per flush) & $\begin{array}{r}75-210 \mathrm{~L} 7 \\
\text { times/day }\end{array}$ & 30 & -15 & No $P$ in additives & -14 \\
\hline Washing clothes & $150-210$ (L per load) & 35-52 L once/week & 15 & -5 & Less food waste & -10 \\
\hline Washing dishes & 50-120 (L per load) & 17-40 L twice/week & 15 & -5 & $\begin{array}{l}\text { More vegetarian } \\
\text { food }\end{array}$ & $-X$ \\
\hline $\begin{array}{l}\text { Prepare food }+ \\
\text { drink }\end{array}$ & No measure & $20 \mathrm{~L}$ & 10 & 0 & & \\
\hline Other & No measure & $20 \mathrm{~L}$ & 10 & 0 & & \\
\hline Subtotal & & $267-492 L$ & 140 & -55 & & $>-30$ \\
\hline \multicolumn{7}{|l|}{ Step 2: reuse } \\
\hline Greywater & 0 & 0 & 0 & -10 & Urine & -31 \\
\hline Blackwater & 0 & 0 & 0 & -2 & Food waste & -5 \\
\hline Subtotal & 0 & 0 & 0 & -12 & & -36 \\
\hline \multicolumn{7}{|l|}{ Step 3: recycle } \\
\hline Greywater & 0 & 0 & 0 & -35 & Faeces & -16 \\
\hline Blackwater & 0 & 0 & 0 & -10 & Food waste & -8 \\
\hline Subtotal & 0 & 0 & 0 & -45 & & -24 \\
\hline
\end{tabular}

Open Access This article is licensed under a Creative Commons Attribution 4.0 International License, which permits use, sharing, adaptation, distribution and reproduction in any medium or format, as long as you give appropriate credit to the original author(s) and the source, provide a link to the Creative Commons licence, and indicate if changes were made. The images or other third party material in this article are included in the article's Creative Commons licence, unless indicated otherwise in a credit line to the material. If material is not included in the article's Creative Commons licence and your intended use is not permitted by statutory regulation or exceeds the permitted use, you will need to obtain permission directly from the copyright holder. To view a copy of this licence, visit http://creativecommons. org/licenses/by/4.0/.
Publisher's Note Springer Nature remains neutral with regard to jurisdictional claims in published maps and institutional affiliations.

Jan-Olof Drangert $(\bowtie)$

Address: Department of Water and Environmental Studies, Linköping University, Linköping, Sweden.

e-mail: janolof.drangert@gmail.com 